\title{
Exploring the determinants of on-farm transitions: Evidence from rural China
}

\author{
Hao WANG ${ }^{\mathrm{a}, *}$, Jan FIDRMUC ${ }^{\mathrm{b}}, \mathrm{Qi}_{\mathrm{LUO}}^{\mathrm{c}}$ and Mingzhong LUO ${ }^{\mathrm{d}}$
}

\begin{abstract}
To shed light on the sustainable development of rural areas, we study the determinants of transitions from subsistence farming into either formal agricultural employment or agricultural entrepreneurship based on a recent nationally representative survey dataset. We pay particular attention to the roles of different capital endowments broadly including human, financial, natural, social and political capital. Our results show that, human, natural, social and political capital are all important determinants of rural households' transitions to on-farm employment and entrepreneurship while financial capital plays a limited role. These findings are robust to fully controlling for off-farm transitions as part of the household occupational strategy.
\end{abstract}

JEL Codes: D13; O18; Q10; Q12

Keywords: Rural development; On-farm transitions; Capital endowments; Labor allocation

\footnotetext{
* Corresponding author.

a School of Economics, Shenzhen University, Shenzhen, 518060, China; Department of Economics and Finance, School of Slavonic and East European Studies, University College London, Bloomsbury, WC1H 0BW, United Kingdom; Department of Economics and Finance, Brunel University London, Uxbridge, UB8 3PH, United Kingdom. Email: haobu@bu.edu

b Department of Economics and Finance and CEDI, Brunel University London, Uxbridge, UB8 3PH, United Kingdom; PRIGO University, Havířov; Institute for Strategy and Analysis (ISA), Government Office of the Slovak Republic; CESifo Munich; Rimini Centre for Economic Analysis (RCEA), and Global Labor Organization (GLO). Email: Jan.Fidrmuc@ @runel.ac.uk

c School of Economics and Management, Guangdong University of Finance and Economics, Guangzhou, 510320, China. Department of Economics and Finance, Brunel University London, Uxbridge, UB8 3PH, United Kingdom. Email: luoqi@gdufe.edu.cn

${ }^{\mathrm{d}}$ College of Economics and Management, South China Agricultural University, Guangzhou, Guangdong, 510640, China. Email: luomingzhong@scau.edu.cn
} 


\section{Introduction}

Traditionally, mainstream development literature has seen the rural sector primarily as a source of cheap migrant labor facilitating incipient industrialization in urban areas (e.g., Lewis, 1954; Harris and Todaro, 1970), rather than being interesting in its own right. Similarly, policy makers prioritized the development of urban areas. This long existing uneven interplay between rural and urban development has the potential to undermine economic and political stability, especially for developing countries like China.

Since the economic reforms initiated in 1978, China has undergone tremendous changes. Between 1978 and 2014, it has grown on average by just under 10\% per year (Lau, 2015). This has been achieved by improving the productivity of rural agriculture so as to release workers into manufacturing in urban areas. Despite industrialization during the early Maoist period (in particular during the Great Leap Forward of 195862 ), $82 \%$ of the Chinese population remained in rural areas by 1978 . Under Maoism, rural households were organized in people's communes (RenMinGongShe 人民公社) which shared both work responsibilities and fruits of their joint efforts. This resulted in poor incentives, low productivity and freeriding. In the early 1980s, the communes were disbanded and replaced by the Household Responsibility System (JiaTingZeRenZhi 家庭 责任制) ${ }^{1}$, which divided the commune's resources (including land) and its output quota among the individual households. The households thus regained responsibility for their output, and were free to keep any surplus left after delivering their share of the quota (Lin, 1992).

At the outset of reforms, in the early 1980s, the bulk of rural residents was therefore engaged in lowproductivity agriculture on land controlled by their household. After the relaxation of Hukou restrictions ${ }^{2}$, a migration from rural to urban areas started in the late 1980s, with rural migrants seeking better job opportunities alongside better education and medical services in urban centers. As with other emerging economies, there is an extensive body of research capturing this process in China, referred in the literature as off-farm (or non-farm) transitions (e.g., Zhang and Song, 2003; Shi et al., 2007; Li et al., 2016; Tian et al., 2016; Wang et al., 2011; Lei et al., 2013; Wang et al., 2016). However, in contrast to the attention given to the transformation of urban areas and rural to urban migration, there has been much less work on studying the onfarm transitions, which can be defined as transfers of workers from low-productivity subsistence farming to

\footnotetext{
${ }^{1}$ Household Responsibility System was first adopted in agriculture in 1979. In the traditional Maoist organization of the rural economy, farmers were given a quota by the government specifying the quantity of goods to produce. They received a reward for meeting the quota. Going beyond the quota rarely produced a further economic reward.

2 'Hukou' is a household registration system, which designates all individuals as either rural or urban residents. In the past, individuals were expected to remain in the area stated in their Hukou, and changing either one's status (from rural to urban) or place of residence was difficult. Even at present, individuals with a rural Hukou have limited access to public goods and services in urban areas.
} 
either formal agricultural employment or entrepreneurial activity in agriculture (as opposed to moving away from rural agriculture into manufacturing in the urban areas).

In this paper, therefore, we study what drives the livelihood decisions of on-farm transitions in rural China. Our empirical strategy is based on a comprehensive rural household survey dataset covering 9 provinces from East, Central and West China. In doing so, we focus on households rather than individuals as the decision making in livelihood transitions is a profit maximizing and risk minimizing process of a household (Stark, 1984, Taylor, 1987). In this sense, the allocation of household labor is a joint decision involving all family members as a whole. To preview the findings, we find that human, natural social and political capital are important determinants of rural households' transitions to on-farm employment and entrepreneurship while financial capital plays a limited role. These findings are robust to fully controlling for off-farm transitions as part of the household occupational strategy.

The contributions of our study are threefold. First, we shed light on the sustainable development of rural areas. Chinese government and President Xi proposed and adopted the "Rural Revitalization Strategy (XiangCunZhenXin 乡村振兴)" in the 19th Communist Party of China National Congress in 2017, which aims to promote the sustainable development of rural sector. The ability of rural households to undertake on-farm transitions is of crucial importance to facilitate this strategy for primary reasons. On the one hand, on-farm transitions stimulate agricultural productivity (Haggblade et al., 2010; Levine, 2014; Zhan, 2017), which in turn both increases the wellbeing of those who stay in rural areas, and releases labor from agriculture which can then move to urban areas and help sustain economic growth there. On the other hand, on-farm transitions promote rural livelihood diversity, which in turn helps suppress rural poverty and promotes rural sustainability (Bebbeington, 1999; Ellis, 1998; Ellis, 2000; Haggblade et al., 2010). We observe rural households in 2015, some 35 years after the reforms were initiated. Although we do not observe when the transitions happen, given that the vast majority of rural households shared the same initial situation in the early 1980s, our analysis captures the outcomes of any on-farm transitions that had happened since then.

Second, our study closely relates to the literature on agrarian changes. The diversity of rural livelihood strategies is central to the rural development (Bebbington, 1999; Scoones, 2009; Chambers, 2008). Such diversity, which is also beneficial to the households, is determined by various factors such as seasonality, risk, and credit markets (Ellis, 2000). Ellis's framework has been followed by a small number of studies centering on the Chinese context. By observing different types of rural households, Zhang (2015) develops a classification of agrarian class positions and argues that government plays an important role in rural 
development. Similarly, Yan and Chen (2015) posit that on-farm entrepreneurship is driven by the government as engine of rural development. Zhan (2017) also contends that these agrarian changes are driven by government subsidies as a form of capital accumulation. These studies focus more on the role of government policies but overlook the internal factors such as the households' own capacity of driving agrarian changes. While the previous studies are mostly qualitative and case-study oriented, we add to the literature by providing a quantitative angle at the subject matter.

Third, the literature has explicitly recognized that capital endowments are pivotal determinants of household livelihood strategy (e.g., Bebbington, 1999; Bhandari, 2013; Moyes et al., 2015; Wang et al., 2016; Tregear and Cooper, 2017; Inwood, 2017). Rural households often differ considerably in their resources, reflecting different local circumstances, past effort, resources inherited from their elders, and even luck. Therefore, unlike extant research attributing the agrarian changes mainly to financial capital accumulation in rural China (Zhan, 2017; Yan and Chen, 2015), we elaborate on this literature by examining to what extent other types of capital endowments can contribute to on-farm transitions, with capital defined broadly. In addition, we explicitly consider social and political capital. The Guanxi (networks and relationships) matters enormously in the Chinese society, especially in rural areas (Zhang et al., 2012; Jin et al., 2014). Similarly, rural cadres are responsible for key political and administrative decisions affecting rural residents' off-farm employment (Zhang et al., 2003). Our study thus can show how different types of capital endowments contribute to the incidence of rural livelihood transitions.

The remaining part of this paper proceeds as follows. The next section reviews the relevant literature. Section 3 describes the data and outlines the methodology. Section 4 presents the results and discusses the findings. Section 5 conducts a robustness check by taking off-farm transitions into account and section 6 concludes.

\section{Drivers of rural development in China}

The process of economic development of an emerging economy is usually understood in the context of the interplay between rural and urban sectors (Lewis, 1954; Harris and Todaro, 1970). Economic transformation is set off by industrialization in the urban sector, which becomes the source of economic growth. The rural sector instead serves as a pool of abundant labor, with the bulk of rural workforce initially languishing in lowproductivity subsistence agriculture. The plentiful supply of cheap rural labor supports the development of the urban sector: as manufacturing expands, rural workers move to the cities to take advantage of the higher wages 
there. This continuous influx of new workers keeps urban wage growth in check (in addition, if the urban wages are downward sticky, involuntary urban unemployment can arise as a consequence or rural to urban migration of labor). Eventually, the pool of labor in the rural sector becomes exhausted. When this happens, both rural and urban wages start growing rapidly: this phenomenon is referred to as the Lewis turning point. When the developing economy passes the turning point, the resulting urban wage growth constraints further expansion of manufacturing: to continue growing, productivity improvements become necessary.

The jury is still out on the question whether China has already reached or even passed the Lewis turning point. On the one hand, Liu (2015) observes that both rural wages and agricultural productivity started to increase sharply around 2002-04. He therefore, argues that China reached the turning point around that time. On the other hand, Das and N'Diaye (2013) point out that the supply of low-wage labor in rural areas of China still remains large. They therefore anticipate China to arrive at the turning point only by 2020-2025.

In line with the literature's focus on the urban areas being where economic change takes place, the models of development are primarily concerned with off-farm transitions. However, Ranis (2004) argues that some countries experienced industrialization accompanied by concurrent dramatic improvements in agricultural productivity. He argues this was the case of England at the cusp of $18^{\text {th }}$ century, Japan in the late $19^{\text {th }}$ and early $20^{\text {th }}$ century, and Taiwan during the 1950 s and 1960 s. Such productivity improvements helped release further labor from agriculture while keeping the agricultural wage at or close to the subsistence level. Therefore, successful on-farm rural transitions can restrain the pressure on wages to increase and thus help facilitate further growth of urban manufacturing.

At present, $41.5 \%$ of China's population live in the rural areas. The traditional sector's share in the economy, however, is relatively low: agriculture accounts for $27.7 \%$ of total employment but only $7.92 \%$ of GDP (NBSC, 2017). The disparity between the sector's contributions to employment and output are consistent with the observation that large stock of excess labor still remains in rural areas (Das and N'Diaye, 2013).

With the liberalization of capital accumulation and the implementation of favorable agricultural policies, rural China is experiencing a transition from a tightly regulated peasant economy to a more open market economy (Long and Liu, 2016). As a result, on-farm entrepreneurship and on-farm employment are emerging as alternatives to subsistence farming on household-held plots (Yan and Chen, 2015; Zhang, 2015; Zhan, 2017). Accordingly, rural residents who do not move to urban areas have three options: remaining in low-productivity subsistence farming (that is, continuing to work on the family farm), leaving the family farm by taking up formal employment in an agricultural firm, or setting up their own agricultural firm (Xia and Simmons, 2007; 
Wang et al., 2016). Which of these options they choose crucially depends on the resources at their disposal: savings and access to loans, skills and training, connections (both social and political), and the like. In other words, the occupational strategy depends crucially on the resource they possess. These resources often display the characteristics of capital stocks: they are costly to build (both in terms of monetary outlays and time and effort) and, if not regularly maintained, they tend to lose their value gradually over time. The endowments considered in this study include both tangible and intangible capital stocks: human; financial, natural, social, and political capital. Below, we briefly discuss the classification of capital endowments and what effects we expect them to have.

Human capital can help facilitate on-farm transitions. It corresponds to the skills and knowledge (innate and acquired) embodied in labor (Tan, 2014; Bhandari, 2013; Inwood, 2017). As an important dimension of human capital, education plays a crucial role in decision making of rural households (Bhandari, 2013). For instance, Zhang et al. (2002) find that those who are more educated obtain more off-farm opportunities. Similarly, Wang et al. (2016) show that there is a strongly positive relationship between human capital investment and entrepreneurship as well as holding a managerial position. We expect education to have a similar impact on on-farm transitions: possessing formal education and having agricultural and/or entrepreneurial skills should help rural residents become agricultural entrepreneurs.

With respect to gender, most studies (based on experimental evidence or observing investment behavior of men and women) tend to find that women are generally more risk averse (Jianakoplos and Bernasek 1998; Eckel and Grossman, 2008; Sarin and Wieland, 2016). Becoming an owner of an agricultural business is associated with more uncertainty and risk than formal employment ( Ahn, 2010; Hvide and Panos, 2013). Therefore, we expect that rural households with higher share of women will prefer formal on-farm employment rather than a transition into on-farm entrepreneurship.

Rural workers who migrated to urban areas in the past benefit from experience and skills that workers who never left the rural region lack. The migrant-worker experience can be helpful both with respect to finding formal on-farm employment as well as when it comes to setting up on-farm businesses. Thus, we expect household with former rural-to-urban migrants to be more likely to undertake either type of on-farm transition.

Financial capital should also be significantly associated with on-farm transitions. Income, bank deposits, bonds and equity, and bank loans are essential determinants of firm growth (e.g., Fowowe, 2017; Lee and Stebunovs, 2016). In the context of rural China, where a large portion of households fall in the low-income group, lack of access to bank loans and other types of external finance can restrain their ability to set up new 
agricultural businesses. Agricultural subsidies can be another financial resource for rural households. Therefore, we expect on-farm transitions to be positively affected by the household's ability to benefit from government subsidies, especially so with respect to transitions into on-farm entrepreneurship.

Importantly, natural capital has the potential to be the most important determinant of on-farm transitions (Kimhi and Bollman, 1999; Goetz and Debertin, 2001; Bhandari, 2013; Li et al., 2016). By investigating the extend of farmland fragmentation, for example, Su et al., (2014) conclude that the quality, quantity and the fragmentation of farmland have significant impacts on migration decisions. We anticipate the effect of quantity of farmland to be negative with respect to transition into employment: more land requires greater labor input from the household members. In contrast, households with more land should be in a better position to start an agricultural business (and hire labor external to the household to work on the land). Finally, the expected impact of farmland fragmentation is negative for both types of transitions: fragmented land requires more time and effort from the household members.

Additionally, social capital can also play a role in on-farm transitions in the literature as it can facilitate transactions, reduce freeriding, influence goals and to expand access to better opportunities (e.g., Fidrmuc and Gërxhani, 2008; Bhandari, 2013; Moyes et al., 2015). As an important type of social capital in China, Guanxi represents the size of the network of relatives and acquaintances who can offer information and assistance in gathering resources and cementing business ties. Similarly, a common surname is considered as a sign of kinship with other bearers of the same name. ${ }^{3}$ We expect social capital to boost the propensity to undergo onfarm transitions into both on-farm employment and entrepreneurship.

Similarly, political capital can also be tightly linked to on-farm transitions. It is similar to Guanxi or can be treated as a special form of Guanxi in its potential to improve business ties and open doors to new opportunities. It refers to networks established on the basis of political rather than social connections, such as being related to or friends with government officials. Political capital can have a profound impact on rural residents' labor market performance in the sense that helps them get have better information on occupational opportunities (Wang et al, 2016). Cadres, for example, hold most important political positions in China's rural communities. When attempting to start an on-farm business, the access to market information is of crucial

\footnotetext{
${ }^{3}$ Unlike most other countries, China has a relatively few unique surnames, with 100 most common surnames accounting for $84.7 \%$ of the population of the country (see 公安部统计 : "王"成中国第一大姓, 有 9288 万人 (Public Security Bureau Statistics: 'Wang' Found China's \#1 Surname, Includes 92.88m People)." Available at: http://news.eastday.com/c/20070424/u1a2791347.html (accessed 28-01-2018). The three most common surnames, Wang (王), Li (李), and Zhang (张) account for 7.3\%, 7.2\% and 6.8\%, respectively, of the Chinese population ( $92.9 \mathrm{mn}, 92.1 \mathrm{mn}$ and $87.5 \mathrm{mn}$ in absolute numbers). However, there are important regional differences in the popularity of surnames. For the purposes of our survey, respondents were asked only whether their name was popular in the village.
} 
importance. The cadres can thus open door to success as entrepreneurs (Zhang et al., 2012). We therefore expect political capital to be particularly important in facilitating on-farm transitions into entrepreneurship.

\section{Data and methodology}

\subsection{Data}

Our data is based on the survey entitled "Cultivation and Reform of Land and Relevant Factors in Rural China" carried out by South China Agriculture University in 2015. The survey was conducted in the following steps. First, 31 provinces (including municipalities and autonomous regions) were classified into 3 groups by a cluster analysis of population, per capita GDP, agricultural acreage, proportion of agricultural acreage, proportion of agricultural population and proportion of agricultural production. Second, 9 provinces were selected randomly across Eastern, Central and Western China, namely, Guangdong, Guizhou, Henan, Jiangsu, Jiangxi, Liaoning, Ningxia, Shanxi and Sichuan. These provinces are listed in Table 1 and their locations within China are shown and Fig. 1. Counties were then randomly chosen from each province again. Finally, 240 households were randomly chosen in each of the selected areas to participate in the survey. ${ }^{4}$ To ensure the quality of collected data, the final questionnaire was developed on the basis of a pilot survey. Survey was conducted through faceto-face interviews and 2880 households participated in the survey. Eliminating invalid questionnaires (those with incomplete or inconsistent responses), the final sample contains 2704 rural households. Table A in the Appendix details more information on the cluster analysis for the survey.

Table 1

Surveyed provinces.

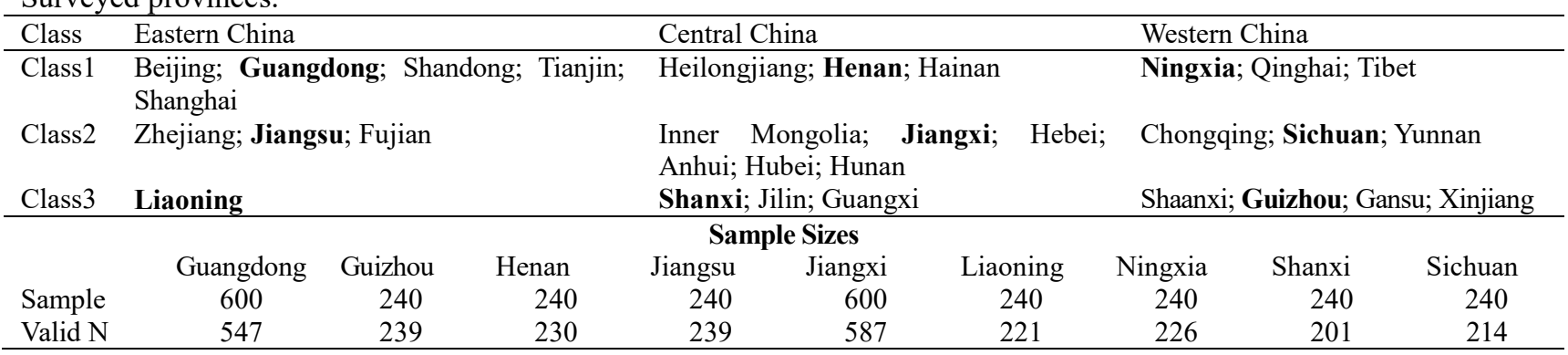

${ }^{4}$ Larger samples were selected in two of the provinces. 


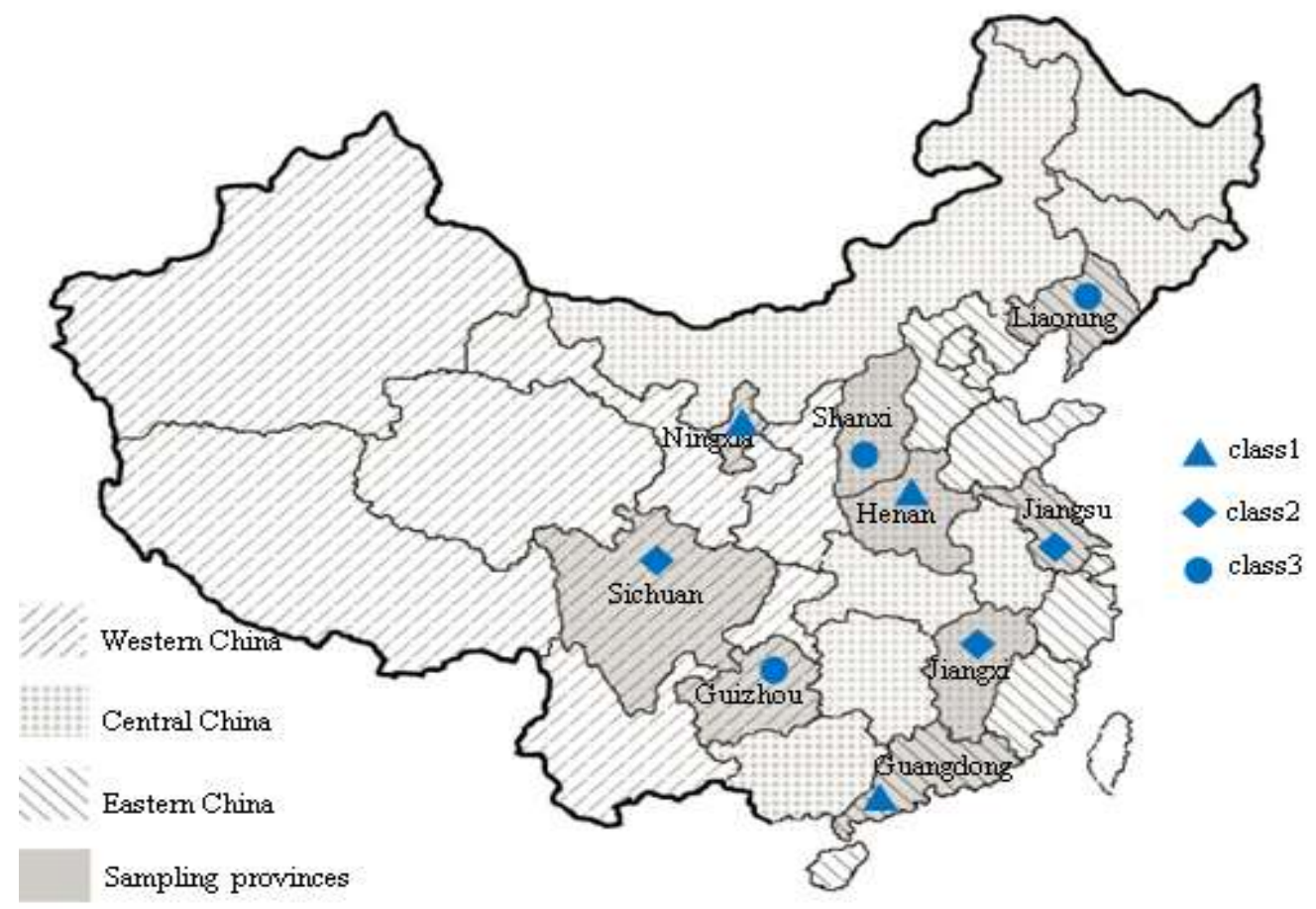

Fig. 1. Location of surveyed provinces.

The dependent variable in our empirical analysis, the household's decision to undertake on-farm transition, takes four values, as given by the categorical choices shown in Table 2 . No household members in formal on-farm employment or own an agribusiness is denoted with 0 ; one or more household members as onfarm workers (and none as business owners) is option 1; one or more household members becoming entrepreneurs (and none in formal employment) is valued with 2; household members in both on-farm employment and others concurrently as agribusiness owners is denoted with 3 .

\section{Table 2}

Descriptive of dependent variable.

\begin{tabular}{lcc}
\hline On-farm transitions. & $\mathrm{N}$ & Proportion \\
\hline No household member as on-farm worker or agribusiness owner $=0$ & 2147 & $79.40 \%$ \\
Household members as on-farm worker $=1$ & 409 & $15.13 \%$ \\
Household members as agribusiness owner $=2$ & 116 & $4.29 \%$ \\
Household members as both on-farm worker and agribusiness owner $=3$ & 32 & $1.18 \%$ \\
\hline
\end{tabular}

The explanatory variables of interest, the capital endowments of the household are presented in Table 3 . Note that the survey only collects information about the whole household, not about individual household members (with the exception of the household head).

Human capital is measured by the number of economically active household members, their gender distribution, average educational attainment, history of training, and experience of rural-to-urban migration. 
Households with more workers and more educated and trained members are believed to have higher human capital endowments (Schultz, 1961; Wang et al., 2016; Muchomba, 2017). Specifically, we set the length of compulsory education in China, nine years, as the threshold level of education, and distinguish between households whose average education level is 9 or less and those with greater values. As for training, the Chinese government has funded non-profit organizations to offer training programs, which the farmers can receive for free (Pan et al, 2017). We therefore include a measure whether members of the household have received such training.

Financial capital is measured by household's income, savings, access to bank credit, and agricultural subsidies. Specifically, we include the household's total income, relative comparison of present income with the past and with other households, and having savings and/or bank loans.

Natural capital is measured as the household's contracted farmland, actual farmland used, land quality, and the relative size of land holdings. Farmland and land quality are indicators of the condition of the natural capital base. However, due to the limited farmland and the implementation of Household Responsibility System in the late 1970s and early 1980s that followed the principle of equality in farmland allocation (according to household size, the number of active members in a household, or both), farming operations in rural China are small and fragmented. Therefore, we use the farmland fragmentation as an additional measure of the condition of farmland.

Social capital is measured by the number of relatives/friends that the household has and whether the family surname is popular in the village. In rural China, due to the small scale of villages and limited geographical mobility, people sharing the same surname may belong to the same extended family or a wider clan. They may be more willing to help each other as a result. For the same reason, the authorities in the village are more likely to be selected from among those with the most popular surnames.

Political capital is measured as household members holding positions of village cadres, and membership of household members in the Communist Party of China (CPC). Both cadre status inside and outside the village is taken into accounts as on-farm transitions can take place both inside and outside the village. Being a CPC member can help by facilitating better political connections, which in turn can translate into economic gains. 
Table 3

Descriptive statistics of explanatory variables and control variables.

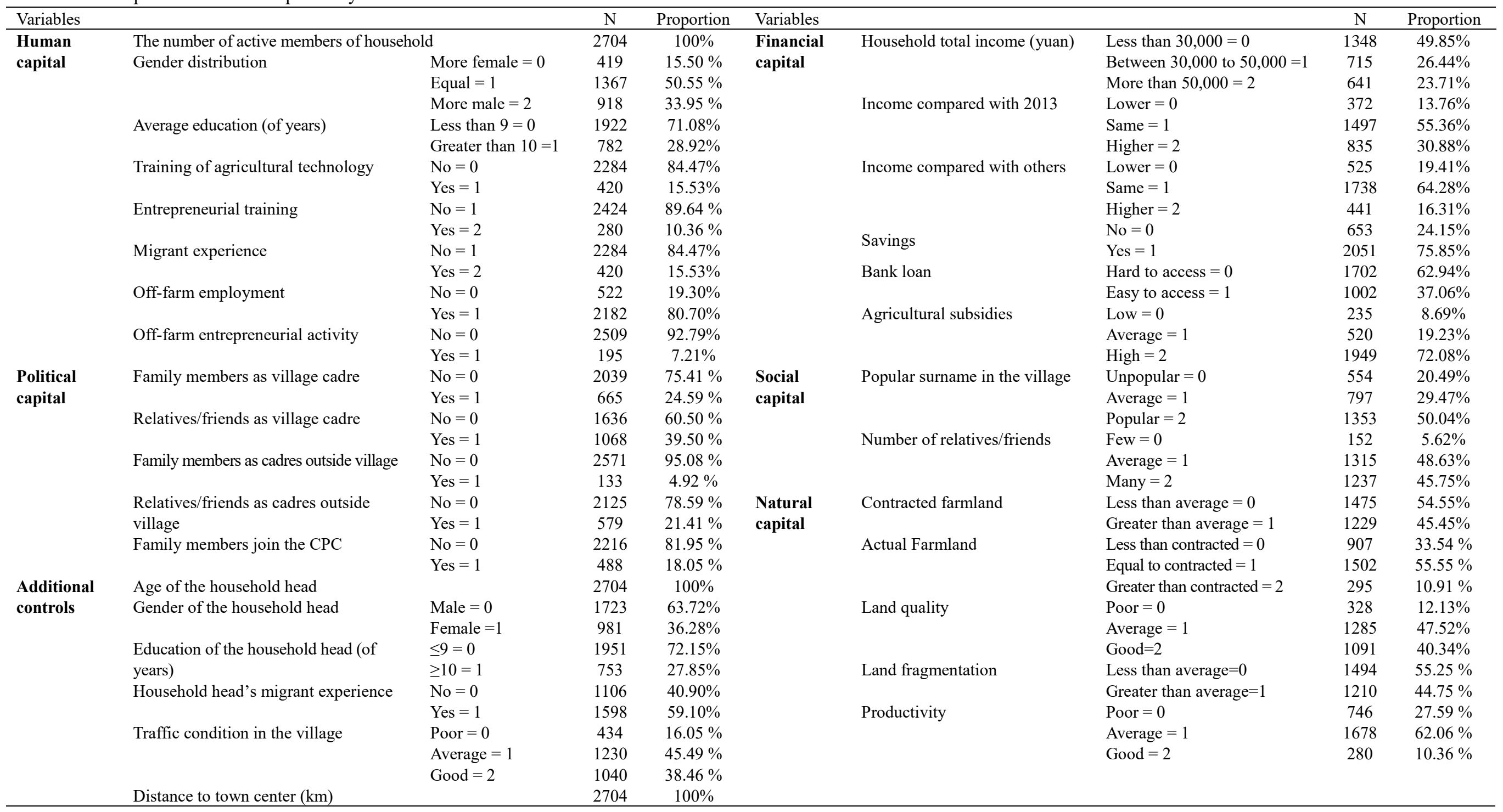


A number of additional control variables are included in the analysis. These mostly reflect the information available about the household head (the only member of the household whose details are reported in the survey). We therefore control the socio-economic characteristics of the household heads including their age, gender, educational level and migrant work experience. Furthermore, we also control traffic condition and distance to the center of township, which reflect the local conditions in the village.

\subsection{Methodology}

On-farm transitions are essentially a set of decisions on occupational choice with multiple options. We follow the studies on occupational choice and adopt the Multinomial Logit Model, which has been widely adopted in empirical analyses with categorical variables (Greene, 2007; Schmidt and Strauss, 1975; Barkley, 1990; Wang et al., 2016). The utility function for the household occupational choice is specified as follows.

$$
U_{i j}=\alpha+G X_{i}^{\prime}+\varepsilon_{i j}
$$

where $U_{i j}$ is the utility of household $i$ associated with choice $j . X_{i}^{\prime}$ is a vector of household characteristics and $G$ is a vector of parameters to be estimated. The probability that option $j$ is chosen by $i$ can be written as follows.

$$
P_{i j}=\operatorname{Prob}\left(Y_{i j}=1\right)=\frac{\exp \left(G_{j} X_{i}^{\prime}\right)}{\sum_{i=1}^{M} \exp \left(G_{i} X_{i}^{\prime}\right)} \quad j=0,1,2 \ldots N ; i=1,2,3 \ldots . M
$$

Note that we set decision $j=0$ as denoting those household with no members as either on-farm workers or agribusiness owners as the base category; $j=1$ if at least one household member is and on-farm worker (and none are agribusiness owners); $j=2$ when at least one household member is a local agribusiness owner (and none are formally employed in agriculture); and $j=3$ when at least one household member is an on-farm worker and at least one is an agribusiness owner. Note that only 32 households fall into the last category; therefore, we take the results for this group with a grain of salt and focus in our discussion on households for which $\mathrm{j}$ equals 1 or 2 .

The analysis proceeds in two steps. We first only include the capital endowments. Then, we also include the additional control variables (household head characteristics and local conditions) as well as province fixed effects, which can capture the effect of local-level factors that also affect rural on-farm transitions and whose effects are the same for all households in the same sampling location: policies put in place by the local 
government (and the extent to which implementation of national policies differs across regions), local-level institutions, and access to market.

\section{Results and discussions}

Table 4 reports the marginal effect of different types capital endowments obtained in a multinomial logit households' on-farm transitions. Column 1 - 3 are estimated without additional controls and column 4 - 6 with additional control variables and province fixed effects.

Table 4

Determinants of on-farm transitions: multinomial logit, marginal effects. $(\mathrm{N}=2704)$

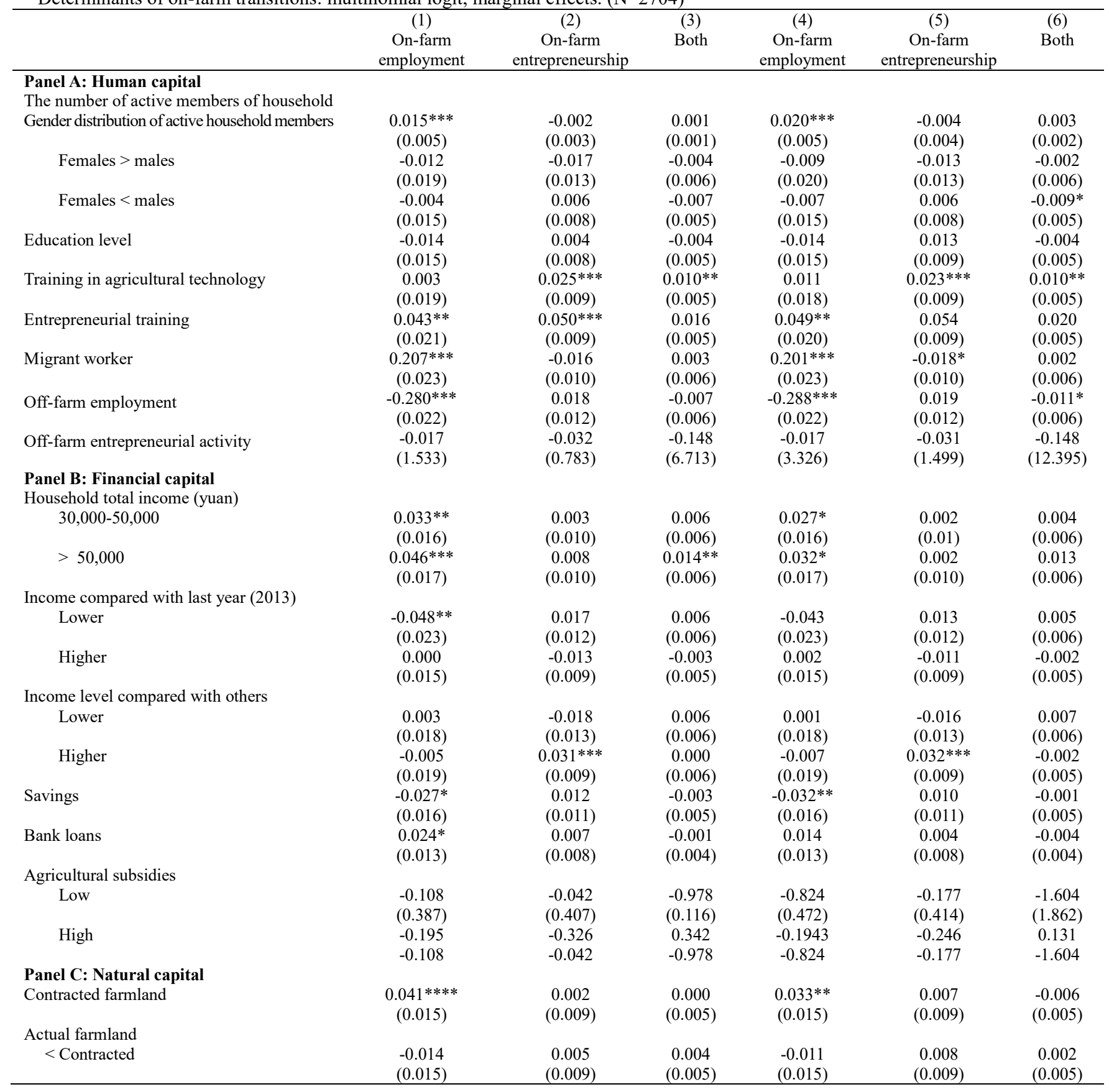




\begin{tabular}{|c|c|c|c|c|c|c|}
\hline$>$ Contracted & $\begin{array}{c}0.002 \\
(0.021)\end{array}$ & $\begin{array}{c}0.027 * * * \\
(0.010)\end{array}$ & $\begin{array}{c}0.017 * * * \\
(0.005)\end{array}$ & $\begin{array}{c}0.010 \\
(0.021)\end{array}$ & $\begin{array}{c}0.031 \\
(0.011)\end{array}$ & $\begin{array}{c}0.016 \\
(0.005)\end{array}$ \\
\hline \multicolumn{7}{|l|}{ Land quality } \\
\hline Poor & $\begin{array}{l}-0.007 \\
(0.023)\end{array}$ & $\begin{array}{l}-0.002 \\
(0.015)\end{array}$ & $\begin{array}{c}-0.001 \\
(0.009)\end{array}$ & $\begin{array}{l}-0.007 \\
(0.022)\end{array}$ & $\begin{array}{c}0.000 \\
(0.015)\end{array}$ & $\begin{array}{l}-0.003 \\
(0.009)\end{array}$ \\
\hline Good & $\begin{array}{c}0.037 * * * \\
(0.014)\end{array}$ & $\begin{array}{l}0.016^{*} \\
(0.008)\end{array}$ & $\begin{array}{l}0.01 * * \\
(0.005)\end{array}$ & $\begin{array}{c}0.030 * * \\
(0.014)\end{array}$ & $\begin{array}{l}0.016^{*} \\
(0.009)\end{array}$ & $\begin{array}{l}0.010^{*} \\
(0.005)\end{array}$ \\
\hline Land fragmentation & $\begin{array}{c}-0.028^{*} \\
(0.015)\end{array}$ & $\begin{array}{l}-0.001 \\
(0.009)\end{array}$ & $\begin{array}{c}0.006 \\
(0.005)\end{array}$ & $\begin{array}{l}-0.023 \\
(0.018)\end{array}$ & $\begin{array}{c}0.011 \\
(0.010)\end{array}$ & $\begin{array}{c}0.008 \\
(0.006)\end{array}$ \\
\hline \multicolumn{7}{|l|}{ Productivity } \\
\hline Low & $\begin{array}{l}-0.011 \\
(0.016)\end{array}$ & $\begin{array}{c}0.012 \\
(0.009)\end{array}$ & $\begin{array}{c}-0.009 \\
(0.006)\end{array}$ & $\begin{array}{l}-0.013 \\
(0.015)\end{array}$ & $\begin{array}{c}0.010 \\
(0.009)\end{array}$ & $\begin{array}{c}-0.009 \\
(0.006)\end{array}$ \\
\hline High & $\begin{array}{l}0.041^{*} \\
(0.021)\end{array}$ & $\begin{array}{l}0.021^{*} \\
(0.012)\end{array}$ & $\begin{array}{c}0.006 \\
(0.006)\end{array}$ & $\begin{array}{l}0.037^{*} \\
(0.021)\end{array}$ & $\begin{array}{c}0.020 \\
(0.012)\end{array}$ & $\begin{array}{c}0.006 \\
(0.006)\end{array}$ \\
\hline \multicolumn{7}{|l|}{ Panel D: Social capital } \\
\hline Unpopular & $\begin{array}{c}-0.05 * * * \\
(0.019)\end{array}$ & $\begin{array}{c}0.016 \\
(0.011)\end{array}$ & $\begin{array}{c}-0.004 \\
(0.005)\end{array}$ & $\begin{array}{c}-0.046^{* *} \\
(0.018)\end{array}$ & $\begin{array}{c}0.016 \\
(0.011)\end{array}$ & $\begin{array}{l}-0.003 \\
(0.005)\end{array}$ \\
\hline \multicolumn{7}{|l|}{ Number of relatives or friends } \\
\hline Few & $\begin{array}{c}-0.054 * \\
(0.032)\end{array}$ & $\begin{array}{l}-0.014 \\
(0.021)\end{array}$ & $\begin{array}{c}0.002 \\
(0.009)\end{array}$ & $\begin{array}{c}-0.053^{*} \\
(0.032)\end{array}$ & $\begin{array}{c}-0.013 \\
(0.021)\end{array}$ & $\begin{array}{c}0.006 \\
(0.009)\end{array}$ \\
\hline Many & $\begin{array}{c}-0.044 * * * \\
(0.014)\end{array}$ & $\begin{array}{c}-0.004 \\
(0.008)\end{array}$ & $\begin{array}{c}0.004 \\
(0.005)\end{array}$ & $\begin{array}{c}-0.040 * * * \\
(0.014)\end{array}$ & $\begin{array}{c}-0.001 \\
(0.008)\end{array}$ & $\begin{array}{c}0.003 \\
(0.005)\end{array}$ \\
\hline \multicolumn{7}{|l|}{ Panel E: Political capital } \\
\hline Family members as village cadres & $\begin{array}{c}0.039 * * \\
(0.016)\end{array}$ & $\begin{array}{c}0.026 * * * \\
(0.009)\end{array}$ & $\begin{array}{c}0.001 \\
(0.005)\end{array}$ & $\begin{array}{c}0.042 * * * \\
(0.016)\end{array}$ & $\begin{array}{c}0.024 * * * \\
(0.009)\end{array}$ & $\begin{array}{c}0.001 \\
(0.005)\end{array}$ \\
\hline Relatives/friends as village cadres & $\begin{array}{c}0.015 \\
(0.015)\end{array}$ & $\begin{array}{c}0.000 \\
(0.008)\end{array}$ & $\begin{array}{l}0.008^{*} \\
(0.005)\end{array}$ & $\begin{array}{c}0.017 \\
(0.014)\end{array}$ & $\begin{array}{l}-0.003 \\
(0.008)\end{array}$ & $\begin{array}{c}0.010 * * \\
(0.005)\end{array}$ \\
\hline Family members as cadres outside village & $\begin{array}{c}0.000 \\
(0.031)\end{array}$ & $\begin{array}{c}0.009 \\
(0.015)\end{array}$ & $\begin{array}{c}0.007 \\
(0.007)\end{array}$ & $\begin{array}{c}-0.004 \\
(0.030)\end{array}$ & $\begin{array}{c}0.002 \\
(0.015)\end{array}$ & $\begin{array}{c}0.008 \\
(0.007)\end{array}$ \\
\hline Relatives/friends as cadres outside village & $\begin{array}{c}0.012 \\
(0.017)\end{array}$ & $\begin{array}{c}0.002 \\
(0.009)\end{array}$ & $\begin{array}{c}0.001 \\
(0.005)\end{array}$ & $\begin{array}{c}0.002 \\
(0.016)\end{array}$ & $\begin{array}{c}0.004 \\
(0.009)\end{array}$ & $\begin{array}{c}0.002 \\
(0.005)\end{array}$ \\
\hline Family members join the CPC & $\begin{array}{c}-0.034^{*} \\
(0.019)\end{array}$ & $\begin{array}{l}-0.008 \\
(0.01)\end{array}$ & $\begin{array}{c}0.001 \\
(0.005)\end{array}$ & $\begin{array}{l}-0.030 \\
(0.019)\end{array}$ & $\begin{array}{l}-0.006 \\
(0.010)\end{array}$ & $\begin{array}{c}0.002 \\
(0.005)\end{array}$ \\
\hline Age square & & & & $\begin{array}{c}0.000 \\
(0.000)\end{array}$ & $\begin{array}{c}0.000 \\
(0.000)\end{array}$ & $\begin{array}{c}0.000 \\
(0.000)\end{array}$ \\
\hline Gender & & & & $\begin{array}{l}-0.016 \\
(0.014)\end{array}$ & $\begin{array}{l}-0.003 \\
(0.008)\end{array}$ & $\begin{array}{l}-0.006 \\
(0.005)\end{array}$ \\
\hline Household head's educational level & & & & $\begin{array}{c}0.009 \\
(0.018)\end{array}$ & $\begin{array}{l}-0.020 \\
(0.011)\end{array}$ & $\begin{array}{l}-0.001 \\
(0.006)\end{array}$ \\
\hline Household head migrant experience & & & & $\begin{array}{c}0.034 \\
(0.014)\end{array}$ & $\begin{array}{c}0.001 \\
(0.008)\end{array}$ & $\begin{array}{c}0.003 \\
(0.004)\end{array}$ \\
\hline \multicolumn{7}{|l|}{ Traffic condition in the village } \\
\hline Poor & & & & $\begin{array}{c}-0.055 \\
(0.021)\end{array}$ & $\begin{array}{c}-0.008 \\
(0.013)\end{array}$ & $\begin{array}{l}-0.005 \\
(0.008)\end{array}$ \\
\hline Good & & & & $\begin{array}{c}0.019 \\
(0.014)\end{array}$ & $\begin{array}{c}0.012 \\
(0.009)\end{array}$ & $\begin{array}{l}-0.003 \\
(0.005)\end{array}$ \\
\hline Distance from home to town & & & & $\begin{array}{c}0.001 \\
(0.001)\end{array}$ & $\begin{array}{c}0.000 \\
(0.001)\end{array}$ & $\begin{array}{c}0.000 \\
(0.000)\end{array}$ \\
\hline Province fixed effects & No & No & No & Yes & Yes & Yes \\
\hline
\end{tabular}

Notes: (1)-(3) are benchmark models and (4)-(6) are with additional control variables; Standard errors are in parentheses; Significant level: ${ }^{*} \mathrm{p}<0.1{ }^{* *} \mathrm{p}<0.05 * * * \mathrm{p}<0.01$.

The results for human capital shown in Panel A suggest that having more active household members increases the probability of transitioning into on-farm employment. Note that we control for the amount of land that the household can use: holding the area of farmland constant, larger households are more likely to have surplus labor that can move into formal employment elsewhere. In contrast, the number of active members of household has no influence on the probability of undergoing transition into agribusiness. Training plays an important role, as expected: entrepreneurial training exerts significantly positive influence on on-farm 
transition into both employment and entrepreneurship while agricultural training fosters only moving into onfarm entrepreneurship. Migrant work experience of a household member has positive influence on transition into employment, while it has no impact on transition into entrepreneurship: former migrant workers probably have history of urban employment, and are likely to have acquired human capital that makes them more productive in rural employment as well. As expected, the number of household members employed off-farm has a negative effect on transitioning to on-farm worker status: with more household members working offfarm, there are fewer members available to work on-farm. Off-farm employment does not, however, have significant influence on on-farm entrepreneurship. Having household members owning off-farm business has no significant effect on either type of on-farm transition. Finally, gender balance of the household and education of household members do not significantly contribute to either type of transition, contrary to our expectations.

The effect of financial capital on on-farm transitions is reported in Panel B. The higher the income of a household, the more likely it is to transition into on-farm employment. This may reflect reverse causality: being employed outside the household brings in additional earnings, resulting in an overall increase in the household's income. This interpretation is consistent also with the finding that household with employed members are less likely to report falling earnings compared with the previous year. Current income does not have a direct impact on on-farm entrepreneurship. Nevertheless, households with higher than average incomes are likely to have members who are agribusiness owners. Having savings makes formal employment less likely; contrary to our expectations, savings do not affect the transition into entrepreneurship. Bank loans have the opposite effect, being positively correlated with on-farm employment but not with being an agribusiness owner. The coefficient of bank loans on entrepreneurship is somewhat surprising: it suggests that agricultural business owners rely little on external finance, or find it difficult to obtain it, unlike those in formal employment who can borrow from banks against future earnings from employment. In addition, the level of agricultural subsidies does not have a significant effect, which can be explained by the limited extent of government subsidies (Park et al., 1998; Meng, 2012).

In Panel C, we assess how natural capital contributes to on-farm transitions. Households with larger than average amount of farmland are more likely to transition into on-farm employment. Having access to more land than contracted, in turn, is associated with greater probability of entrepreneurship: this may be an effect of transitioning into entrepreneurial activity rather than a driver of it, as agribusiness owners may seek to acquire additional land. On the other hand, households with land of better-than-average quality and with better 
than average productivity tend to have members transitioning into formal employment (after controlling for the amount of land). Land of better quality should be easier to work on, and this should help release some household members to seek employment elsewhere. Likewise, higher productivity of land means that less labor and other inputs are required to work on the given quantity of land, again helping release surplus labor into formal employment.

Panel D reports the effect of social capital on on-farm transitions. The results display an inverted Ushaped relationship between social capital and transitioning into formal employment. That is, both having a popular and unpopular surname is associated with lower probability of on-farm employment transition than having a surname of average popularity. Similarly, those with few and many friends are less likely to transition into on-farm employment than those with an intermediate number of friends. A popular surname probably means that many residents in the village share the same surname: this may result in weaker ties among those with that surname. In contrast, having an unpopular surname means that there are few kinsmen in the village. Interestingly, the effects of the two types of social capital on on-farm agribusiness transition are different: those with popular surnames are (weakly) more likely to move into rural entrepreneurship while having more than average number of friends has no effect on this type of transition.

Panel E outlines the effect of political capital on on-farm transitions. The results show that having a family member as a village cadre has a positive effect on the probability of both types of on-farm transition. Such cadres could potentially help their family members through different channels. For instance, rural cadres can use their position to help family members gain better access to higher-level bureaucrats, potential business partners and employers, credit sources, market information or technical expertise (Oi, 1999; Zhang et al, 2012, Jin et al., 2014). Interestingly, the positive effect only appears when a household member is a village cadre: having more distant relatives or friends as village cadres, or having a family member as a cadre outside the village, have no significant influence on on-farm transition. This finding is consistent with Zhang and $\mathrm{Li}$ (2003) who also find that having family members as cadre has a significant effect on off-farm employment while the impact of having ties outside the village is insignificant. This is captured also in a Chinese proverb: "Distant water will not quench a fire nearby (YuanShuiJiuBuLeJinHuo 远水救不了近火). Hence, the depth of political capital is much more important than its width. It is also interesting that having household members in the Communist Party of China has a weakly negative effect on the likelihood of on-farm employment and no significant effect on on-farm entrepreneurship: this may either mean that CPC members receive few benefits, 
or that the Party membership helps them move out of agriculture into off-farm employment or career in the civil service while having no impact on livelihood improvements while remaining in agriculture.

The results presented in column (4) -(6) when we control for additional variables and province fixed effects are well-aligned with the estimates in column (1) -(3). In particular, we find that the age of the household head has a positive effect on the decision to transition as on-farm worker (note that in this case, the age of household head is related to the probability of any household member transitioning into on-farm employment). We also note that poor traffic conditions in the village discourage on-farm transition into employment. Somewhat surprisingly, however, the gender and education level of the household head do not have a significant effect on either type of transition.

To sum up, we reproduce our prior expectations and compare them with our findings in Table 5. Our expectations have been broadly confirmed with respect to human and natural capital, and also, though less firmly, for social and political capital. Rather surprisingly, the results of our analysis suggest that financial capital plays a limited role as a catalyst of rural on-farm transitions.

\section{Table 5}

Expected effects of capital endowments vs empirical results.

\begin{tabular}{|c|c|c|c|c|}
\hline \multirow[t]{2}{*}{ Capital endowment } & \multicolumn{2}{|c|}{ On-farm employment } & \multicolumn{2}{|c|}{ On-farm entrepreneurship } \\
\hline & Expectation & Finding & Expectation & Finding \\
\hline \multicolumn{5}{|l|}{ Human capital } \\
\hline Education & + & 0 & + & 0 \\
\hline Training & + & + & + & ++ \\
\hline Share of females & + & 0 & - & 0 \\
\hline Former rural-to-urban migrants & 0 & + & + & 0 \\
\hline \multicolumn{5}{|l|}{ Financial capital } \\
\hline Income & 0 & + & + & + \\
\hline Savings & 0 & - & ++ & 0 \\
\hline Bank loans & 0 & + & ++ & 0 \\
\hline Agricultural subsidies & 0 & 0 & + & 0 \\
\hline \multicolumn{5}{|l|}{ Natural capital } \\
\hline Quality of farmland & + & ++ & ++ & + \\
\hline Quantity of farmland & - & ++ & + & + \\
\hline Land fragmentation & - & - & - & 0 \\
\hline \multicolumn{5}{|l|}{ Social capital } \\
\hline Friends and relatives & + & $+/-$ & ++ & 0 \\
\hline Popular surname & + & $+/-$ & ++ & ++ \\
\hline \multicolumn{5}{|l|}{ Political capital } \\
\hline Household members cadres & + & ++ & ++ & ++ \\
\hline Friends/relatives cadres & + & 0 & ++ & 0 \\
\hline Household CPC members & + & 0 & ++ & 0 \\
\hline
\end{tabular}

\section{Robustness check: taking account of both on-farm and off-farm transitions}

The above analysis is focused on on-farm transitions and to what extent they are driven by capital endowments. However, members of rural households can also migrate to urban areas to seek jobs or set up businesses there. 
This is referred to as off-farm transitions (e.g., Wang et al., 2011; Wang et al., 2013; Wang et al., 2016). When household members move away to engage in off-farm transitions, the same person is no longer able to undertake on-farm transitions. Hence, on-farm transitions and off-farm transitions are both part of the households' occupational choice set as substitutes. So far, we account for this by constructing explanatory variables that capture whether household members have undertaken off-farm transitions. An alternative treatment is to include both on-farm and off-farm transitions among the household choice set: that is, to include off-farm transitions in the construction of the dependent variable.

Accounting fully for both on-farm and off-farm transitions yields 16 possible combinations as shown in Table 6. We designate undergoing neither off-farm transitions nor on-farm transitions (12.09\% of households) as the base category. The most common outcomes are off-farm employment with no on-farm transitions (60.98\%), off-farm employment with concurrent on-farm employment $(9.06 \%)$, combination of off-farm employment and off-farm entrepreneurship with no on-farm transitions (5.70\%), on-farm employment with no off-farm transitions (5.33\%), and off-farm employment and on-farm entrepreneurship (3.51\%). The remaining $3.33 \%$ are households undertaking other combinations of on-farm and off-farm transitions. Each of these remaining combinations is too small to be analyzed separately, therefore, we aggregate then into an other category. We thus estimate multinomial logit of the probability of choosing one of the aforementioned combinations (marked in bold type in Table 6), relative to the probability of the base option of no transition (in bold and italics).

Table 6

Occupational choice matrix.

\begin{tabular}{|c|c|c|c|c|c|}
\hline & $\begin{array}{c}\text { No off-farm } \\
\text { transitions }\end{array}$ & $\begin{array}{c}\text { Off-farm } \\
\text { employment }\end{array}$ & $\begin{array}{c}\text { Off-farm } \\
\text { entrepreneurship }\end{array}$ & Off-farm both & Total \\
\hline No on-farm transitions & $\begin{array}{c}327 \\
(12.09 \%)\end{array}$ & $\begin{array}{c}1649 \\
(60.98 \%)\end{array}$ & $\begin{array}{c}17 \\
(0.63 \%)\end{array}$ & $\begin{array}{c}154 \\
(5.70 \%)\end{array}$ & $\begin{array}{c}2147 \\
(79.4 \%)\end{array}$ \\
\hline On-farm employment & $\begin{array}{c}144 \\
(5.33 \%)\end{array}$ & $\begin{array}{c}245 \\
(9.06 \%)\end{array}$ & $\begin{array}{c}8 \\
(0.30 \%)\end{array}$ & $\begin{array}{c}12 \\
(0.44 \%)\end{array}$ & $\begin{array}{c}409 \\
(15.13 \%)\end{array}$ \\
\hline On-farm entrepreneurship & $\begin{array}{c}17 \\
(0.63 \%)\end{array}$ & $\begin{array}{c}95 \\
(3.51 \%)\end{array}$ & $\begin{array}{c}0 \\
(0.00 \%)\end{array}$ & $\begin{array}{c}4 \\
(0.15 \%)\end{array}$ & $\begin{array}{c}116 \\
(4.29 \%)\end{array}$ \\
\hline On-farm both & $\begin{array}{c}9 \\
(0.33 \%)\end{array}$ & $\begin{array}{c}23 \\
(0.85 \%)\end{array}$ & $\begin{array}{c}0 \\
(0.00 \%)\end{array}$ & $\begin{array}{c}0 \\
(0.00 \%)\end{array}$ & $\begin{array}{c}32 \\
(1.18 \%)\end{array}$ \\
\hline Total & $\begin{array}{c}497 \\
(18.38 \%)\end{array}$ & $\begin{array}{c}2012 \\
(74.41 \%)\end{array}$ & $\begin{array}{c}25 \\
(0.92 \%)\end{array}$ & $\begin{array}{c}170 \\
(6.29 \%) \\
\end{array}$ & $\begin{array}{l}2704 \\
(100 \%)\end{array}$ \\
\hline
\end{tabular}

Table 7 reports the effect of capital endowments on combinations of off-farm and on-farm transitions. For the ease of comprehension, we denote the columns headings with combinations of letters indicating the presence of transition into employment (E) or into business (B), which can take place on-farm (in rural area, R) or off-farm (urban, U). The effects of human capital are presented in Panel A. The coefficient of agricultural 
technology training in column (5) is positive and statistically significant, which means that receiving training in agricultural technology increase the probability of households undergoing on-farm entrepreneurial activity and off-farm employment. Entrepreneurial training lowers the probability of off-farm employment while it boosts on-farm transitions into both employment and agricultural entrepreneurship as shown in column (2) and (5). Column (1), (2) and (5) suggest that having migrant experience has an ambiguous effect: positive for onfarm and off-farm employment but negative for on-farm entrepreneurial activity.

The effect of financial capital is presented in Panel B. We observe that having household income between $30 \mathrm{~K}$ and $50 \mathrm{~K}$ is negatively associated with transitioning into off-farm employment but has a positive impact on moving into on-farm employment as shown in column (1) and (4). Households reporting lower income level compared to the previous year is negatively related to on-farm employment while having higher income compared to other household is positively related to on-farm transitions (both as on-farm workers and agribusiness entrepreneurs). Having higher savings leads to lower probability of being both off-farm and onfarm employed. Higher level of agricultural subsidies has a positive effect on the combinations with off-farm employment and on-farm transitions.

Panel C reports the effect of natural capital. As expected, column (1) shows that having more contracted land and land of better quality reduce the probability of off-farm employment while column (4) and (5) show that higher productivity, quality and more contracted land boost on-farm transitions. The effect of social capital, shown in Panel D, suggests that having a popular surname and many friends both have a negative effect on on-farm employment, which broadly corroborates our previous finding. As for the effect of political capital, in Panel E, what matters the most is again having family members who hold the post of a local cadre. Households that benefit from a family member being a cadre tend to initiate on-farm transitions of both types.

\section{Table 7}

Determinants of combination of off-farm and on-farm transitions: multinomial logit, marginal effect. .

\begin{tabular}{|c|c|c|c|c|c|c|}
\hline & $\begin{array}{l}\text { (1) } \\
\text { UE }\end{array}$ & $\begin{array}{c}\text { (2) } \\
\text { UE \& RE }\end{array}$ & $\begin{array}{c}\text { (3) } \\
\text { UE \& UB }\end{array}$ & $\begin{array}{l}(4) \\
\mathrm{RE}\end{array}$ & $\begin{array}{c}\text { (5) } \\
\text { UE \& RB }\end{array}$ & $\begin{array}{c}(6) \\
\text { Others }\end{array}$ \\
\hline \multicolumn{7}{|l|}{ Panel A: Human capital } \\
\hline The number of active members of household & $\begin{array}{c}0.016^{* * *} \\
(0.008)\end{array}$ & $\begin{array}{c}0.013 * * * \\
(0.004)\end{array}$ & $\begin{array}{c}0.004 \\
(0.004)\end{array}$ & $\begin{array}{c}0.004 \\
(0.004)\end{array}$ & $\begin{array}{l}-0.001 \\
(0.003)\end{array}$ & $\begin{array}{l}-0.001 \\
(0.003)\end{array}$ \\
\hline \multicolumn{7}{|l|}{ Gender distribution } \\
\hline Females $>$ males & $\begin{array}{l}0.046^{*} \\
(0.027)\end{array}$ & $\begin{array}{c}-0.003 \\
(0.016)\end{array}$ & $\begin{array}{l}-0.011 \\
(0.013)\end{array}$ & $\begin{array}{l}-0.014 \\
(0.014)\end{array}$ & $\begin{array}{c}-0.002 \\
(0.011)\end{array}$ & $\begin{array}{l}-0.009 \\
(0.011)\end{array}$ \\
\hline Females $<$ males & $\begin{array}{c}0.040^{* *} \\
(0.020)\end{array}$ & $\begin{array}{l}-0.001 \\
(0.012)\end{array}$ & $\begin{array}{l}-0.013 \\
(0.010)\end{array}$ & $\begin{array}{l}-0.015 \\
(0.010)\end{array}$ & $\begin{array}{c}0.007 \\
(0.008)\end{array}$ & $\begin{array}{l}-0.010 \\
(0.008)\end{array}$ \\
\hline Education level & $\begin{array}{l}-0.018 \\
(0.021)\end{array}$ & $\begin{array}{l}-0.003 \\
(0.013)\end{array}$ & $\begin{array}{c}0.016 \\
(0.010)\end{array}$ & $\begin{array}{l}-0.004 \\
(0.010)\end{array}$ & $\begin{array}{c}0.011 \\
(0.008)\end{array}$ & $\begin{array}{l}-0.008 \\
(0.009)\end{array}$ \\
\hline Training in agricultural technology & $\begin{array}{c}0.017 \\
(0.026)\end{array}$ & $\begin{array}{c}0.015 \\
(0.015)\end{array}$ & $\begin{array}{c}-0.039 * * * \\
(0.014)\end{array}$ & $\begin{array}{c}-0.029 * * \\
(0.014)\end{array}$ & $\begin{array}{c}0.019 * * \\
(0.008)\end{array}$ & $\begin{array}{c}0.017 * * \\
(0.008)\end{array}$ \\
\hline Entrepreneurial training & $\begin{array}{c}-0.105^{* * * *} * \\
(0.031)\end{array}$ & $\begin{array}{c}0.037 * * \\
(0.016)\end{array}$ & $\begin{array}{c}0.056 * * * \\
(0.011)\end{array}$ & $\begin{array}{c}0.021 \\
(0.015)\end{array}$ & $\begin{array}{c}0.036 \text { **** } \\
(0.009)\end{array}$ & $\begin{array}{c}0.035^{* * * *} \\
(0.009)\end{array}$ \\
\hline Migrant working experience & $\begin{array}{c}0.204 * * * \\
(0.024)\end{array}$ & $\begin{array}{c}0.102 * * * \\
(0.017)\end{array}$ & $\begin{array}{c}0.013 \\
(0.010)\end{array}$ & $\begin{array}{c}-0.028 * * * \\
(0.008)\end{array}$ & $\begin{array}{c}0.003 \\
(0.007)\end{array}$ & $\begin{array}{c}-0.018 * * * \\
(0.006)\end{array}$ \\
\hline
\end{tabular}




\begin{tabular}{|c|c|c|c|c|c|c|}
\hline \multicolumn{7}{|l|}{ Panel B: Financial capital } \\
\hline \multirow{2}{*}{$30,000-50,000$} & $-0.044 * *$ & \multicolumn{5}{|c|}{ Household total income (yuan) } \\
\hline & $(0.022)$ & $(0.013)$ & $(0.011)$ & $(0.010)$ & $\begin{array}{l}-0.004 \\
(0.009)\end{array}$ & $(0.009)$ \\
\hline \multirow{2}{*}{$>50,000$} & -0.030 & 0.011 & 0.006 & $0.031 * *$ & -0.003 & $0.020 * *$ \\
\hline & $(0.024)$ & $(0.014)$ & $(0.012)$ & $(0.012)$ & $(0.009)$ & $(0.009)$ \\
\hline \multicolumn{7}{|l|}{ Income level compared with 2013} \\
\hline \multirow[t]{2}{*}{ Lower } & 0.042 & $-0.039 * *$ & 0.003 & -0.023 & 0.004 & $0.024 * *$ \\
\hline & $(0.029)$ & $(0.020)$ & $(0.015)$ & $(0.014)$ & $(0.011)$ & -0.010 \\
\hline \multirow[t]{2}{*}{ Higher } & 0.017 & -0.001 & 0.008 & -0.006 & $-0.015 *$ & 0.000 \\
\hline & $(0.020)$ & $(0.012)$ & $(0.010)$ & $(0.010)$ & $(0.008)$ & $(0.008)$ \\
\hline \multicolumn{7}{|l|}{ Income level compared with others } \\
\hline \multirow[t]{2}{*}{ Lower } & -0.018 & 0.006 & -0.014 & 0.009 & -0.011 & 0.005 \\
\hline & $(0.025)$ & $(0.015)$ & $(0.014)$ & $(0.011)$ & $(0.011)$ & -0.010 \\
\hline Higher & -0.029 & -0.013 & $0.024 * *$ & -0.007 & $0.025^{* * *}$ & 0.010 \\
\hline & $(0.026)$ & $(0.016)$ & $(0.011)$ & $(0.012)$ & $(0.009)$ & $(0.009)$ \\
\hline Savings & 0.022 & $-0.029 * *$ & $0.023^{*}$ & -0.015 & 0.003 & 0.006 \\
\hline & $(0.022)$ & $(0.013)$ & $(0.013)$ & $(0.010)$ & $(0.010)$ & $(0.009)$ \\
\hline Bank loans & -0.007 & 0.011 & $-0.016^{*}$ & 0.011 & 0.005 & $-0.013^{*}$ \\
\hline & $(0.019)$ & $(0.011)$ & $(0.010)$ & $(0.009)$ & $(0.007)$ & $(0.007)$ \\
\hline Agricultural subsidies & & & & & & \\
\hline Low & 0.812 & 0.724 & 0.821 & 0.608 & 0.605 & 1.228 \\
\hline & $(0.297)$ & $(0.331)$ & $(0.405)$ & $(0.317)$ & $(0.343)$ & $(0.748)$ \\
\hline High & $0.523 * * *$ & $0.435 * * *$ & $0.493^{* *}$ & 0.608 & $0.394 * *$ & 0.549 \\
\hline & $(0.130)$ & $(0.131)$ & $(0.162)$ & $(0.205)$ & $(0.143)$ & $(0.220)$ \\
\hline Panel C: Natural capital & & & & & & \\
\hline Contracted farmland & $-0.055^{* * * *}$ & $0.041 * * *$ & $-0.021 *$ & 0.004 & 0.003 & -0.003 \\
\hline & $(0.021)$ & $(0.013)$ & $(0.011)$ & $(0.010)$ & $(0.008)$ & $(0.008)$ \\
\hline Actual farmland & & & & & & \\
\hline$<$ Contracted & 0.004 & -0.015 & $0.027 * * *$ & -0.009 & 0.010 & 0.009 \\
\hline & $(0.021)$ & $(0.012)$ & $(0.010)$ & $(0.010)$ & $(0.008)$ & $(0.008)$ \\
\hline$>$ Contracted & $-0.060 * *$ & 0.022 & -0.009 & -0.016 & $0.017 *$ & $0.032 * * *$ \\
\hline & $(0.030)$ & $(0.017)$ & $(0.018)$ & $(0.015)$ & $(0.010)$ & $(0.009)$ \\
\hline Land quality & & & & & & \\
\hline Poor & -0.013 & -0.014 & 0.017 & $0.023^{*}$ & 0.003 & -0.024 \\
\hline & $(0.030)$ & $(0.020)$ & $(0.015)$ & $(0.013)$ & $(0.013)$ & $(0.015)$ \\
\hline High & $-0.053^{* * * *}$ & 0.017 & -0.001 & $0.021 * *$ & $0.017 * *$ & 0.006 \\
\hline & $(0.020)$ & $(0.012)$ & $(0.010)$ & $(0.010)$ & $(0.008)$ & $(0.008)$ \\
\hline Land fragmentation & -0.007 & $-0.028 *$ & $0.025^{* *}$ & 0.001 & 0.009 & 0.007 \\
\hline & $(0.024)$ & $(0.015)$ & $(0.011)$ & $(0.012)$ & $(0.009)$ & $(0.009)$ \\
\hline Productivity & & & & & & \\
\hline Low & -0.027 & -0.012 & $0.019 * *$ & 0.002 & 0.007 & 0.003 \\
\hline & $(0.021)$ & $(0.013)$ & $(0.010)$ & $(0.010)$ & $(0.008)$ & $(0.008)$ \\
\hline High & -0.025 & 0.005 & -0.009 & $0.024^{*}$ & 0.009 & $0.019 *$ \\
\hline & $(0.030)$ & $(0.018)$ & $(0.017)$ & $(0.013)$ & $(0.012)$ & $(0.011)$ \\
\hline Panel D: Social capital & & & & & & \\
\hline Popular surname & & & & & & \\
\hline Unpopular & 0.013 & -0.025 & 0.002 & -0.018 & $0.021 * *$ & -0.014 \\
\hline & $(0.026)$ & $(0.016)$ & $(0.013)$ & $(0.011)$ & $(0.010)$ & $(0.010)$ \\
\hline Popular & 0.032 & -0.005 & 0.007 & $-0.039 * * *$ & 0.015 & $-0.015^{*}$ \\
\hline & $(0.022)$ & $(0.013)$ & $(0.011)$ & $(0.011)$ & $(0.010)$ & $(0.008)$ \\
\hline Number of relatives or friends & & & & & & \\
\hline Few & 0.039 & -0.038 & 0.018 & -0.013 & -0.028 & 0.006 \\
\hline & $(0.042)$ & $(0.028)$ & $(0.020)$ & $(0.019)$ & $(0.024)$ & $(0.017)$ \\
\hline Many & 0.022 & $-0.044 * * *$ & $0.017^{*}$ & 0.002 & -0.001 & 0.000 \\
\hline & $(0.019)$ & $(0.012)$ & $(0.010)$ & $(0.009)$ & $(0.008)$ & $(0.007)$ \\
\hline Panel E: Political capital & & & & & & \\
\hline Family members as village cadres & $-0.066^{* * *}$ & $0.030 * *$ & -0.006 & 0.010 & $0.023^{* * * *}$ & 0.011 \\
\hline & $(0.023)$ & $(0.013)$ & $(0.011)$ & $(0.011)$ & $(0.008)$ & $(0.008)$ \\
\hline Relatives / friends as village cadre & -0.029 & 0.016 & 0.003 & -0.002 & 0.000 & $0.014^{*}$ \\
\hline & $(0.020)$ & $(0.012)$ & $(0.010)$ & $(0.010)$ & $(0.008)$ & $(0.008)$ \\
\hline Family members as cadres outside the village & 0.038 & -0.001 & 0.006 & -0.041 & 0.007 & $0.025 * *$ \\
\hline & $(0.042)$ & $(0.025)$ & $(0.018)$ & $(0.025)$ & $(0.013)$ & $(0.012)$ \\
\hline Relatives/friends as cadres outside the village & -0.034 & -0.010 & 0.016 & 0.014 & 0.010 & 0.006 \\
\hline & $(0.023)$ & $(0.014)$ & $(0.010)$ & $(0.010)$ & $(0.008)$ & $(0.008)$ \\
\hline Family members join the CPC & 0.030 & -0.012 & 0.006 & -0.012 & -0.007 & -0.001 \\
\hline & $(0.025)$ & $(0.015)$ & $(0.011)$ & $(0.013)$ & $(0.009)$ & $(0.009)$ \\
\hline Control variables & & & & & & \\
\hline Age of the household head & $-0.007 * *$ & $0.005^{* *}$ & 0.002 & 0.001 & -0.001 & 0.001 \\
\hline & $(0.004)$ & $(0.002)$ & $(0.002)$ & $(0.002)$ & $(0.001)$ & $(0.001)$ \\
\hline Age square & $0.000 *$ & $0.000 * *$ & 0.000 & 0.000 & 0.000 & 0.000 \\
\hline & $(0.000)$ & $(0.000)$ & $(0.000)$ & $(0.000)$ & $(0.000)$ & $(0.000)$ \\
\hline Gender & 0.017 & -0.010 & 0.003 & -0.004 & -0.007 & -0.005 \\
\hline & $(0.019)$ & $(0.012)$ & $(0.009)$ & $(0.009)$ & $(0.008)$ & $(0.007)$ \\
\hline Household head's educational level & 0.001 & 0.010 & 0.006 & 0.004 & $-0.023 * *$ & 0.000 \\
\hline
\end{tabular}




\begin{tabular}{|c|c|c|c|c|c|c|}
\hline & $(0.025)$ & $(0.014)$ & $(0.012)$ & $(0.012)$ & $(0.010)$ & $(0.010)$ \\
\hline Household head's migrant experience & $\begin{array}{l}-0.008 \\
(0.019)\end{array}$ & $\begin{array}{c}0.010 \\
(0.012)\end{array}$ & $\begin{array}{c}0.007 \\
(0.009)\end{array}$ & $\begin{array}{l}0.017 * \\
(0.009)\end{array}$ & $\begin{array}{c}-0.002 \\
(0.007)\end{array}$ & $\begin{array}{c}0.005 \\
(0.007)\end{array}$ \\
\hline \multicolumn{7}{|l|}{ Traffic condition in the village } \\
\hline Poor & $\begin{array}{l}0.050 * \\
(0.028)\end{array}$ & $\begin{array}{c}-0.067 * * * \\
(0.020)\end{array}$ & $\begin{array}{c}0.000 \\
(0.014)\end{array}$ & $\begin{array}{c}0.018 \\
(0.012)\end{array}$ & $\begin{array}{c}-0.002 \\
(0.011)\end{array}$ & $\begin{array}{c}-0.008 \\
(0.011)\end{array}$ \\
\hline Good & $\begin{array}{l}-0.019 \\
(0.020)\end{array}$ & $\begin{array}{l}-0.005 \\
(0.012)\end{array}$ & $\begin{array}{c}0.020^{* *} \\
(0.010)\end{array}$ & $\begin{array}{l}0.019 * \\
(0.010)\end{array}$ & $\begin{array}{c}0.010 \\
(0.008)\end{array}$ & $\begin{array}{c}0.006 \\
(0.008)\end{array}$ \\
\hline Distance from home to town & $\begin{array}{l}-0.001 \\
(0.002)\end{array}$ & $\begin{array}{l}-0.001 \\
(0.001)\end{array}$ & $\begin{array}{c}0.000 \\
(0.001)\end{array}$ & $\begin{array}{c}0.002^{* * * *} \\
(0.001)\end{array}$ & $\begin{array}{c}0.000 \\
(0.001)\end{array}$ & $\begin{array}{c}0.001 * * \\
(0.000)\end{array}$ \\
\hline Province fixed effects & Yes & Yes & Yes & Yes & Yes & Yes \\
\hline
\end{tabular}

Notes: Base $=$ no on-farm and off-farm transitions; UE = off-farm (urban) employment with no on-farm transitions; UE \& RE = offfarm (urban) employment and on-farm (rural) employment; UB \& UE = off-farm (urban) transitions (both) with no on-farm transitions; $\mathrm{RE}=$ on-farm (rural) employment with no off-farm transitions; UE \& RB = off-farm (urban) employment with on-farm (rural) business; Others $=$ the rest; Standard errors are in parentheses; Significant level: ${ }^{*} \mathrm{p}<0.1{ }^{* *} \mathrm{p}<0.05 * * * \mathrm{p}<0.01$.

\section{Conclusions}

China has long been attempting to shake off rural poverty and inequality. On-farm transitions, a pathway towards sustainable development of rural areas, therefore deserve greater attention. On the basis of a recent comprehensive survey of rural households, we investigate the effect of households' capital endowments on rural transitions from subsistence farming into either formal on-farm employment or on-farm entrepreneurship.

Contributing to the literature of rural development, our research confirms that capital endowments are important determinants of rural households' livelihood strategies. Yet, the role of financial capital, such as savings and access to bank loans, is limited. Similarly, the government's subsidies do not have a significant impact either. Instead, our results highlight the importance of natural, human, social and political capital. Specifically, investing in human capital, in the form of receiving training in either agricultural technology or entrepreneurial skills, increases the likelihood of transitioning into on-farm employment and entrepreneurship. Former migrant workers, who have returned to their home village, are more likely to find formal employment, suggesting that the experience of rural-to-urban migration improves their employability even in the rural labor market. Both the quality and quantity of farmland are important for on-farm transitions: having land of better quality helps release surplus labor into formal employment. Social capital has non-linear impact on on-farm employment, with intermediate values being more supportive of on-farm employment than either high or low values. Political capital such as having local rural cadres in the village also exerts positive influence on onfarm transition. However, only local political connections matter, whereas political capital outside of the village is less influential. Finally, poor road infrastructure poses a barrier to transition into on-farm employment. A further and deeper analysis with full account of off-farm transitions largely supports these findings.

The findings of our paper add credence to the argument put forward by Ranis (2004) that reaching the Lewis turning point can be postponed if the rural sector experiences productivity improvements in parallel with the growth of the urban sector. Accordingly, rising productivity in the rural areas helps release more labor from agriculture, which, in turn, helps keep rural wages low. Therefore, successful and on-going on-farm transitions can help maintain the high rate of economic growth in China in the years to come.

Our research yields a few policy implications. Our findings help identify factors that facilitate on-farm transitions: acquisition of human capital, both in the shape of formal education and further practical training, facilitating the return of rural-to-urban migrants who bring new skills (and social capital) with them back to 
rural areas, and improvements in the quality of road infrastructure. Policy makers should focus on these areas to encourage on-farm transitions and to facilitate sustainable development of rural areas.

\section{Acknowledgement}

We are grateful to the editor, David A. Peel, and an anonymous referee for their insightful comments. We also thank Biliang Luo, Randolph Bruno, Tian Liu, Jiliang Ma and seminar and conference participants at Brunel, Guangdong University of Foreign Studies, South China Agricultural University, SSEES/UCL, the Chinese Economists Society 2018 China Annual Conference in Hefei and the 30th Chinese Economic Association Annual Conference in the University of Edinburgh for their suggestions. All remaining errors are our own. The financial support of National Natural Science Foundation of China (Grant: 71073155) and National Social Science Foundation of China (Grant: 17AJL031) is acknowledged. The views expressed in this paper are those of the authors and do not necessarily represent the official position of the Government Office of the Slovak Republic. 


\section{References}

Ahn, T. 2010. Attitudes toward risk and self-employment of young workers. Labour Economics 17 (2): $434-442$.

Bebbington, A. 1999. Capitals and Capabilities: A Framework for Analyzing Peasant Viability, Rural Livelihoods and Poverty. World Development 12 (27): 2021-2044,

Bhandari, P. B. 2013. Rural livelihood change? Household capital, community resources and livelihood transition. Journal of Rural Studies 32: 126-136.

Chambers, R. 2008. Revolutions in development inquiry. London: Earthscan.

Das, M., and P. N'Diaye. 2013. Chronicle of a Decline Foretold: Has China Reached the Lewis Turning Point? IMF Working Paper WP/13/26.

de Brauw, A., and S. Rozelle. 2008. Reconciling the returns to education in off-farm wage employment in rural China. Review of Development Economics 12 (1): 57-71.

Eckel, C. C., and P. J. Grossman. 2008. Men, women and risk aversion: Experimental evidence. Handbook of Experimental Economics Results 1: 1061-1073.

Ellis, F. 1998. Survey Article: Household Strategies and Rural Livelihood Diversification. Journal of Development Studies 35 (1): 1-38.

Ellis, F. 2000. The determinants of rural livelihood diversification in developing countries. Journal of Agricultural Economics 51: 289-302.

Fidrmuc, J., and K. Gërxhani. 2008. Mind the gap! Social capital, East and West. Journal of Comparative Economics 36: 264-286.

Fowowe, B. 2017. Access to finance and firm performance: Evidence form African countries. Review of Development Finance 7 (1): 6-17.

Goetz, S. J., and D. L. Debertin. 2001. Why Farmers Quit: A Country-Level Analysis. American Journal of Agricultural Economics 83 (4): 1010-1023.

Greene, W. H. 1997. Econometric Analysis (London: Prentice -Hall International).

Haggblade, S., P. Hazell, and T. Reardon. 2010. The rural non-farm economy: Prospects for growth and poverty reduction. World Development 38: 1429-1441.

Harris, J. R., and M. P. Todaro. 1970. Migration, Unemployment and Development: A Two-Sector Analysis. American Economic Review 60 (1): 126-142.

Hvide, H. K., and G. A. Panos. 2013. Risk tolerance and entrepreneurship', Journal of Financial Economics 111: 200223.

Inwood, S. 2017. Agriculture, health insurance, human capital and economic development at the rural-urban-interface. Journal of Rural Studies 54: 1-14.

Jianakoplos, N. A., and A. Bernasek. 1998. Are women more risk averse? Economic Inquiry 36 (4): 620-630.

Jin, Y. H., M. Y. Fan, M. W. Cheng, and Q. H. Shi. 2014. The economic gains of cadre status in rural China: Investigating effects and mechanisms, China Economic Review 31: 185-200.

Kimhi, A., and R. Bollman. 1999. Family farm dynamics in Canada and Israel: the case of farm exits. Agricultural Economics 21 (1): 69-79.

Lau, L. J. 2015. The Sources of Chinese Economic Growth Since 1978. Institute of Global Economics and Finance Working Paper No. 40, The Chinese University of Hong Kong.

Lee, J. S., and V. Stebunovs. 2016. Bank capital pressures, loan substitutability, and nonfinancial employment. Journal of Economics and Business 83: 44-69.

Lei, C. C., R. G. Zhang, and B. C. Wu. 2013. Labor reallocation in China: 1978-2011. Economic Modelling 35: 668-673.

Levine, S. 2014. How to study livelihoods: bringing a sustainable livelihoods framework to life. Working Paper 22. Secure Livelihoods Research Consortium, Overseas Development Institute, London. 
Lewis, W. A. 1954. Economic Development with Unlimited Supplies of Labour. The Manchester School 22 (2): 139-191.

Li, Q. R., T. S. Amjath-Babu, and P. Zander. 2016. Role of capitals and capabilities in ensuring economic resilience of land conservation efforts: A case study of the grain for green project in China's Loess Hills. Ecological Indicators, 71: 636-644.

Long, H. L., and Y. S. Liu. 2016. Rural restricting in China. Journal of Rural Studies 47: 387-391.

Lin, J. Y. 1992. Rural Reforms and Agricultural Growth in China. American Economic Review 82 (1): 34-51.

Liu, D. 2015. Has the Chinese economy passed the Lewis turning point? Journal of the Asia Pacific Economy 20 (3): 404-422.

Meng, L. 2012. Can grain subsidies impede rural-urban migration in hinterland China? Evidence from field surveys. China Economic Review 23: 729-741.

Moyes, D., P. Ferri, F. Henderson, and G. Whittam. 2015. The stairway to Heaven? The effective use of social capital in new venture creation for a rural business. Journal of Rural Studies 39: 11-21.

Muchomba, F. M. 2017. Women's Land Tenure Security and Household Human Capital: Evidence from Ethiopia's Land Certification. World Development 98: 310-324.

OECD. 2007. Promoting Pro-poor Growth: Policy Guidance for Donors. OECD Publishing. Paris.

Oi, J. 1999. Rural China Takes Off: Institutional Foundations of Economic Reform. University of California Press.

Pan, D., F. B. Kong, N. Zhang, and R. Y. Ying. (2017). Knowledge training and the change of fertilizer use intensity: Evidence from wheat farmers in China. Journal of Environmental Management 197: 130-139.

Park, A., C. Wong, C. Ren, and S. Rozelle 1998. Distributional consequences of reforming local public finance in China. The China Quarterly 147: 1001-1032.

Ranis, G. 2004. Arthur Lewis's contribution to development thinking and policy. The Manchester School 72 (6): $712-$ 723.

Sarin, R., and A. Wieland. 2016. Risk aversion for decisions under uncertainty: Are there gender differences? Journal of Behavioral and Experimental Economics 60: 1-8.

Schmidt, P., and R. P. Strauss. 1975. The prediction of occupations using multiple logit models. International Economic Review 16 (2): 471-486.

Schultz, T. 1961. Investment in human capital. American Economic Review 51 (1): 1-17.

Scoones, I. 2009. Livelihoods perspectives and rural development. Journal of Peasant Studies, 36 (1): 171-196.

Shi, X., N. Heerink, and F. Qu. 2007. Choices between different off-farm employment sub-categories: An empirical analysis for Jiangxi Province, China. China Economic Review 18: 438-455.

Stark, O. 1984. Rural-to-Urban Migration in LDCs: A Relative Deprivation Approach. Economic Development and Cultural Change 32 (3): 475-486.

Su, S. L., Y. N. Hu, F. H. Luo, G. C. Mai, and Y. P. Wang. 2014. Farmland fragmentation due to anthropogenic activity in rapidly developing region. Agricultural System 131: 87-93.

Tan, E. 2014. Human capital theory: a holistic criticism. Review of Educational Research 84 (3), 411-445.

Taylor, E. J. 1987. Undocumented Mexico: US migration and the returns to households in rural Mexico. American Journal of Agricultural Economics 69 (3): 626-638.

Tian, Q., L. Y. Guo, and L. Zheng. 2016. Urbanization and rural livelihoods: A case study from Jiangxi Province, China. Journal of Rural Studies 47: 577-587.

Wang, H., J. Fidrmuc, and Y. Tian. 2018. Growing against the Background of Colonization? Chinese Labor Market and FDI in a Historical Perspective. International Review of Economics and Finance, In press.

Wang, W., Q. Li, and D. Lien. 2016. Human capital, political capital and off-farm occupational choices in rural China. International Review of Economics and Finance 42: 412-422.

Wang, X. B., J. B. Huang, L. X. Zhang, and S. Rozelle. 2011. The rise of migration and the fall of self-employment in 
rural China's labor market. China Economic Review 22: 573-584.

Wang, Y. H., C. L. Chen, and E Araral. 2016. The Effects of Migration on Collective Action in the Commons: Evidence from Rural China. World Development, 88: 79-93.

Xia, Q., and Simmons, C. 2007. Employment and earnings of off-farm activities in rural China (in Chinese). China Labor Economics 42 (1): 57-87.

Yan, H., and Y. Chen. 2015. Agrarian Capitalization without Capitalism? Capitalist Dynamics from Above and Below in China. Journal of Agrarian Changes 15 (3): 366-391.

Zhan, S. 2017. Riding on self-sufficiency: Grain policy and the rise of agrarian capital in China. Journal of Rural Studies 54: 151-161.

Zhang, J., J. Giles, and S. Rozelle. 2012. Does it pay to be a cadre? Estimating the returns to being a local official in rural China. Journal of Comparative Economics 40: 337-356.

Zhang, K. H., and Song, S. 2003. Rural-urban migration and urbanization in China: Evidence from time-series and crosssection analyses. China Economic Review 14: 386-400.

Zhang, L., J. Huang, and S Rozelle. 2002. Employment, emerging labor markets, and the role of education in rural China. China Economic Review 13: 313-328.

Zhang, Q. 2015. Class Differentiation in Rural China: Dynamics of Accumulation, Commodification and State Intervention. Journal of Agrarian Changes 15 (3): 338-365.

Zhang, X. B., and G. Li. 2003. Does guanxi matter to nonfarm employment? Journal of Comparative Economics 1: $315-$ 331. 


\section{Appendix}

Table A

Descriptive statistics of 31 Provinces in China used in the cluster analysis.

\begin{tabular}{|c|c|c|c|c|c|c|}
\hline Province & Population & $\begin{array}{l}\text { per Capita GDP } \\
\text { (ten thousand } \\
\text { yuan) }\end{array}$ & $\begin{array}{l}\text { Agricultural } \\
\text { Acreage (thousand } \\
\text { hectare) }\end{array}$ & $\begin{array}{l}\text { Proportion of } \\
\text { Agricultural } \\
\text { Acreage (\%) } \\
\end{array}$ & $\begin{array}{l}\text { Proportion of } \\
\text { Agricultural } \\
\text { Population (\%) } \\
\end{array}$ & $\begin{array}{l}\text { Proportion of } \\
\text { Agricultural } \\
\text { Production (\%) } \\
\end{array}$ \\
\hline Beijing & 2069 & 8.64 & 231.7 & 13.79 & 13.8 & 0.93 \\
\hline Tianjin & 1413 & 9.12 & 441.1 & 39.03 & 18.45 & 1.52 \\
\hline Hebei & 7288 & 3.65 & 6317.3 & 33.66 & 53.2 & 11.65 \\
\hline Shanxi & 3611 & 3.35 & 4055.8 & 25.95 & 48.74 & 7.00 \\
\hline Inner Mongolia & 2490 & 6.38 & 7147.2 & 6.04 & 42.26 & 7.38 \\
\hline Liaoning & 4389 & 5.66 & 4085.3 & 28.00 & 34.35 & 6.20 \\
\hline Jilin & 2750 & 4.34 & 5534.6 & 29.52 & 46.3 & 9.77 \\
\hline Heilongjiang & 3834 & 3.57 & 11830.1 & 26.01 & 43.1 & 16.91 \\
\hline Shanghai & 2380 & 8.48 & 244.0 & 38.72 & 10.7 & 0.85 \\
\hline Jiangsu & 7920 & 6.83 & 4763.8 & 46.43 & 37 & 5.49 \\
\hline Zhejiang & 5477 & 6.33 & 1920.9 & 18.83 & 36.8 & 3.55 \\
\hline Anhui & 5988 & 2.87 & 5730.2 & 41.02 & 53.5 & 10.85 \\
\hline Fujian & 3748 & 5.26 & 1330.1 & 10.97 & 40.4 & 6.41 \\
\hline Jiangxi & 4504 & 2.88 & 2827.1 & 16.93 & 52.49 & 7.75 \\
\hline Shandong & 9685 & 5.16 & 7515.3 & 48.86 & 47.57 & 7.92 \\
\hline Henan & 9406 & 3.15 & 7926.4 & 47.46 & 57.57 & 13.38 \\
\hline Hubei & 5779 & 3.85 & 4664.1 & 25.09 & 46.5 & 11.18 \\
\hline Hunan & 6639 & 3.34 & 3789.4 & 17.89 & 53.35 & 11.97 \\
\hline Guangdong & 10594 & 5.39 & 2830.7 & 15.73 & 32.6 & 3.91 \\
\hline Guangxi & 4682 & 2.78 & 4217.5 & 17.87 & 56.47 & 13.23 \\
\hline Hainan & 887 & 3.22 & 727.5 & 21.40 & 48.4 & 16.13 \\
\hline Chongqing & 2945 & 3.87 & 2235.9 & 27.17 & 43.02 & 7.38 \\
\hline Sichuan & 8076 & 2.96 & 5947.4 & 12.35 & 56.47 & 11.58 \\
\hline Guizhou & 3484 & 1.97 & 4485.3 & 25.48 & 63.59 & 12.62 \\
\hline Yunnan & 4659 & 2.21 & 6072.1 & 15.84 & 60.69 & 13.56 \\
\hline Tibet & 308 & 2.28 & 361.6 & 0.29 & 77.25 & 7.62 \\
\hline Shaanxi & 3753 & 3.85 & 4050.3 & 19.70 & 49.98 & 10.56 \\
\hline Gansu & 2578 & 2.19 & 4658.8 & 10.25 & 61.25 & 17.42 \\
\hline Qinghai & 573 & 3.30 & 542.7 & 0.75 & 52.56 & 6.18 \\
\hline Ningxia & 647 & 3.62 & 1107.1 & 16.67 & 49.33 & 10.27 \\
\hline Xinjiang & 2233 & 3.36 & 4124.6 & 2.48 & 56.02 & 22.32 \\
\hline
\end{tabular}

Source: China Statistical Yearbook 2013. 